УДК 82.09.17.07.01

https://doi.org/10.23939/sjs2020.01.176

Antonina Tsaruk

Candidate of Philological Sciences,

Senior Lecturer at the Department of Social Sciences,

Information and Archival Affairs

Central Ukrainian National Technical University

Ukraine, Kropyvnytsky city, antonina2015@ukr.net

\title{
COORDINATES OF IHOR PAVLYUK ARTISTIC WORLD
}

\section{(C) Царук Антоніна, 2020}

The article explores one of the main motives for the creative achievement of the People's Shevchenko Prize winner Ihor Pavlyuk - the motive for the spiritual self-identification of the lyrical hero and the trail as a result of conscious moral choice. The emotional-psychological portrait of the world-view of our contemporary protagonist is reflected in the novel-meditation in the poems "Pilgrim" and the lyric collection "Carrier of Dreams" by Igor Pavlyuk. The components of the path motive (space and time) emphasize the intrinsic motivation of existential self-knowledge through communion with the Other, the rejection of social stereotypes of conformism in search of the meaning of life.

The motive of trail is quasi-popular in literature. The poet is looking for a golden ratio between the earthly and the otherworldly, trying to keep a shaky harmony between the perfection of nature and love for people, but after reflecting on their actions he comes to the conclusion that the rotten era feeds on our blood and sacral fear. The metaphorical density of the inner states of the lyrical hero, the process of polarization of the needs of the body and soul, the desire for a border encounter of the poet-god with the "human" devil are noted. In the system of coordinates of the artistic world of Ihor Pavlyuk, the vertical serves as a spiritual support in the twilight of losses of both personal and social nature. The semantic palette is represented by gold, blue, white, bloody and black, reflecting the colors of the national flag and the tragic vision of sacrificial love. The methods of artistic understanding of the polyphonicity of the contemporary soul with a low pain threshold in the unbalanced world are analyzed.

Style dominants, methods of creation of sensual image, peculiarities of combination of folk poetical tradition and innovation in poet's creativity are analyzed, comparative parallels with the coordinates of the world famous writers Taras Shevchenko, George Byron, Jose Saramago, Seamus Heaney, Chingiz Aitmatov, Joseph Brodsky are presented.

Keywords: Ihor Pavlyuk, artistic world, motives of creativity, sensual image, features of style.

Антоніна Царук

\section{КООРДИНАТИ ХУДОЖНЬОГО СВІТУ ІГОРЯ ПАВЛЮКА}

Досліджено один із головних мотивів творчого доробку лауреата Народної Шевченківської премії Ігоря Павлюка - мотив шляху духовної самоідентифікації ліричного героя та сліду як результату свідомого морального вибору. Емоційнопсихологічний портрет світовідчуття нашого сучасника-протагоніста знайшов відображення в романі-медитації у віршах “Паломник" та ліричній збірці "Перевізник мрій” Ігоря Павлюка. Зі складових мотиву шляху (простір i час) акцентовано 
внутрішню мотивацію екзистенційного самопізнання через спілкування 3 Іншим, неприйняття суспільних стереотипів конформізму в пошуку сенсу життя.

Наголошено на квазіпопулярність мотиву сліду в літературі. Поет шукас золотий перетин між земним i потойбічним, намагається утримати крихку гармонію між досконалістю природи і любов'ю до людей, але, осмислюючи “сліди” людської цивілізації, доходить висновку: гнила епоха тримається на нашій крові й печерному страхові. Досліджено метафоричну щільність відображення внутрішніх станів ліричного героя, процес поляризації потреб тіла і душі, прагнення межової зустрічі Бога-поета 3 “олюдненим” дияволом. У системі координат художнього світу Ігоря Павлюка вертикаль слугус духовним опертям у сутінках втрат як особистісного, так і суспільного характеру. Семантична палітра представлена золотим, синім, білим, кривавим і чорним, відбиваючи кольори національного прапора й невідворотність трагізму жертовної любові. Узагальнено засоби художнього осмислення поліфонічності душі сучасника із низьким больовим порогом у розбалансованому світі.

Проаналізовано стильові домінанти, прийоми творення чуттсвого образу, особливості посднання народнопоетичної традиції та новаторства в творчості поета, проведено компаративні паралелі з координатами художніх світів всесвітньо відомих письменників Тараса Шевченка, Джорджа Байрона, Жозе Сарамаго, Шеймаса Хіні, Чингіза Айтматова, Йосипа Бродського в осягненні творчого поступу Ігоря Павлюка.

Ключові слова: Ігор Павлюк; художній світ; мотиви творчості; чуттєвий образ; особливості стилю.

The motive of trail is quasi-popular in literature, fot it turns up a reflection of movement as the essence of life and a consequence of a moral choice in boundary situations that determine the trajectory of a human existence and of mankind, the entire people and, ultimately, world civilization, extrapolating the role of conscience in a constant duel of divine and diabolical in a person's soul. Either way, the motive of a spiritual movement in the titles of the autobiographical meditation verse novel by I. Pavlyuk "Pilgrim" (2017) and the lyrics book "Carrier of Dreams" (2019) is a metaphor for the lyrical hero's ascention to self-identification: meaning a fine line of harmony between the pursuit of love, inner freedom, selfrealization in creativity and the doom to sacrifice in a struggle for the astral light of ideals in the novel; that said the thoughts on oneself, a country and the Earth take the direction of Noah, then Charon, and the vertical of unity of the darling graves and stars of the Milky Way symbolizes the continuity of humanity, encoded in historical memory, in the "Carrier of Dreams".

The poet is looking for a golden ratio between the earthly and the otherworldly, trying to keep a shaky harmony between the perfection of nature and love for people, but after reflecting on their actions he comes to the conclusion that the rotten era feeds on our blood and sacral fear. As a result of the clash between the high and the lowly, the reader is beginning to realize their aversion to the status of teir own involuntary involvement in the accumulation of droppings: this is how the motive of the trail of civilization is being designed, evoking the reminiscence of the novel "Blindness" by the Nobel Prize winner from Portugal José Saramago. In the confrontation between the beautiful and the ugly, artistic energy is born, whose pointe is the Euromaidan that took place in Ukraine in 2014: "Smoke coming out of Euromaidan tires / Reminder of an angel, then of a beast" [4, p. 275], gentle "home" memories of harmony ("Spring is when everything is still holy. / And the grandfather is tending cranes") [4, p. 276] grow into the karmic motive of remorse for collective guilt: the chance to become happy on their own land has been lost.

Catching the world with the help of a poetic word as the diffusion of Evil and Good, opportunistic hedonism and missionaries of passionaries, is a maxim that requires from the narrator of "Pilgrim" the sensitivity of a tree without bark, a consciously exposed nerve. The choice of a genre is motivated: if the movement provides a baggage of fresh visual-sensory impressions, and acquaintances provide an exchange of information matrices, then the process of crystallization of what is known requires the meditative state of a wandering philosopher [6, p. 106]. 
Among the components of the path archetype (movement in space and time), the symbolism of the search for the meaning of life, and therefore, the knowledge of its capabilities and boundaries, deserves particular attention. The meditation novel by I. Pavlyuk and the lyrical poem "Childe Harold's Pilgrimage" by George Byron are two centuries apart, however both pieces of work bear the imprint of the disillusionment of generations who placed their hopes: in the Byron era those were the hopes on the Great French Revolution and the change of Europe after the Napoleonic wars, in the modern history of Ukraine, on the Maidan, the Revolution of Dignity, the response to the neighbor-aggressor in the east. The motive of choosing a path from a specific everyday situation, bringing forward an allusion of conflicts in "Buranny Polang" by Chingiz Aitmatov, "Your train is at nine" by Anatolii Moroz, takes on a common human responsibility meaning ("And through the centuries and for centuries - / The premonition of a train station") [3, p. 182], revealing the multidimensionality of the text interpretation "within the network of historical and linguistic influences" [2, p. 62].

The external conflict of the hero-narrator is reminiscent of the romantic challenge of time, the spiritual deterioration of society and at first glance it is due to the maximalist-subjective perception of evil. But when the diktats of time are assimilated by the dominant trait of an empire with the metonymy of power to sources of fuel resources ("Hisses like gas hisses from pipes, / The blue of times, where everything is venal") [3, p. 60], producing a generalization-gradation of "spiritual nuclear war" [3, p. 67], the chronotope of space evokes a sensual reaction - a comparison with the "dense, abandoned grave" [3, p. 67]. And this is perceived not as a result of the subjectivization of the imagination, but as the sad prediction of the end of history, which has forgotten its own lessons. Thus, the complex interweaving of associations of a personal nature and philosophical generalizations of a conceptual one creates a monolith of image and meaning: a symbol in which sensuality prevails over everything else.

The desire to be dissociated from the corruption of politicians is looking for and finding a way out in confession, articulating the "plurality of unity" of manifestations of self-identification: "The Celt ... / He is disgusted by the public swamp/ <...> The soul of the Cossack, / Is severe and repentant" [3, p. 100], emphasizing enduring values - inner freedom, readiness to fight for what is yours, what is dear to you, for the possibility of realization in "akin" work: "I wrote a poem like a bird nests" [3, p. 110].

The text reaches emotional-informational density due to the author's extremely low pain threshold, his ability to immerse historiosophically into reality, his mastery word proficiency and expressive suggestive methods. Lyrical sketches of the dynamics of movement in space are organically changed into a kaleidoscope of destinies of random fellow travelers, and the vector of pilgrimage is changed from spatial (Leningrad, Siberia, Baikal, Ural, Moscow) to the temporary one, with retrospectives of fates of a race (grandfather's participation in the Ukrainian Insurgent Army), deepening into historical layers, in order to draw a line with boundary identification: "I wish I would have time to grow up to myself, / And then, I see that they bury me too" [3, p. 13]. The motive of escape from the world injustice, which was embodied in the aphorism of the Ukrainian philosopher Hrygory Skovoroda ("The world tried to catch me but could not"), is extrapolated to creative self-realization: "I didn't want to walk in the ranks anymore / once I felt tenderness and madness in myself" [3, p. 14]. The romantic challenge to stereotypes is saturated with a critical mass of historical parallels between the fate of truth-seeking poets who have become victims of the system. The ultimate youthful sincerity is paradoxically combined with a philosophical understanding of the challenge resignation and popular irony, giving rise to maxims crucified on dichotomous connections: "The distance is like one between a coffin and a cradle" [3, p. 21]. In "Pilgrim", the theme of a footprint on the ground as a song is "stitched with the first blood" of the boundary situation of upholding the moral priorities of the young man who opened the heart of poetry. The motive of conscious sacrifice vibrates between the romantic aura and sarcasm: "Here the poets are valued ... / Therefore they are killed, beautiful, / They are kissed like bread, / And their death is praised to the skies" [3, p. 22].

Orphanhood from the autobiographical aspect is projected wider onto the generation of Afghan war participants, their "abandonment" by the authorities is comprehended in order to summarize the orphans of an entire people zombied by the Soviet totalitarian system for obedience and intolerance for dissent, and therefore for passionate poets. These are the results of the first pilgrimage of a Ukrainian graduate to the 
Northern Palmyra, his disappointment in the profession of a military engineer and a passionate desire to become a Ukrainian poet.

The second journey was a forced one, to Siberia, "pursuing the path of birds and ancestors" [3, p. 16]. The natural way for the birds and suffering - for repressed for patriotism and free-thinking. The conceptual antonyms are "string / barbed wire" (the impossibility of excluding a "harmful Bandera" from the university was replaced by correctional labour on the construction of the Siberian road, which did not lead anywhere), therefore psychologically the whole world is perceived as hostile to the hero ("birch bark of evil skies") [3, p. 17]. But the way to Baikal is both literary and historical reminiscences, the suggestion of the golden fire of Prometheus condemned to eternal punishment, and the conquest of Siberia by the Cossacks, and the ineradicable free men will, which produces both a challenge to fate and sarcasm to the "common" mother Russia, as the successor of the empire, and its own isolation in the language aspect. This initiation absorbed the path of identification of many generations: "Like a sleeve embroidered with a dulib, / A soul blossomed / with white on white" [3, p. 31], "I am going back, golden like a Moon, / As if I was coming back from a war: devastated, malevolent" [3, p. 57]. The return reflects the maturing of the narrator as a poet-citizen, he is ready to testify against the "white stone" of Moscow with "blood of peoples wounded in the soul" [3, p. 22], the blood that illuminates the ruby stars of the Kremlin and therefore "salty granite blooms red" [3, p. 12]. The return to the home Volyn acquires the symbolic sound of the return of the "prodigal son" to the sources of spirituality and common human values: love, family, work, creativity, freedom: the ideal formulated by Taras Shevchenko: "Then in your own house you will see. True justice, strength, and liberty!" [7, p. 288], to the folk-poetic symbolism: "A black and red swan from a rushnik, / Like a prophetic dream ..." [3, p. 57].

"The Dnipro metaphor lives in me, / here is its depths laughing into space" [3, p. 51] - this testifies to the vital pillar of the universal scale, the acquired faith. The creative discoveries in the architectonics of the work include the distinction between the parties of the "inner voice" and "the voice of the chronicler", which is dictated by the author's attitude to self-deprecation of the chronicler, controlled by the customer, by the scribe's desire to become famous. The opposition to him of the poet's inner voice is obvious: his novel with glory strives for its zenith: the poet dreams of dying in a duel, then fame is doomed to love him forever. He remains a maximalist who cannot be caught by the ringing of coins, who perceives life as a movement along the vertical of spiritual perfection, and the world around him as a palette depending on the inner state, therefore we see the semantic-color diffusion of gold ("a soul is like a goldfish" [3, p. 375], "golden grass" [3, p. 42], "golden friendship" [3, p. 200], "in the golden gorge of loneliness" [3, p. 115], "golden shackles" [3, p. 20]), white as a symbol of purity ("white road" [3, p. 8], "white inner sky" [3, p. 80]), victory and happiness ("and again I am on a white horse", "bathing a white horse at night" [3, p. 200]), and pain ("getting snow off the soul as getting cast off the body" [3, p. 81]).

The persistent unity of the poles is snow white and blood red ("the first snows are stitched with the first blood" [3, p. 24]). Blue in the perception of the pilgrim is the color of indifference and peace, movement to nowhere, to the dead waters of Styx ("The blue of times" [3, p. 60], "blue honey" of the road [3, p. 69]). And at the subconscious level the poet reflects with metonymy persistent metamorphosis in the perception of the combination of colors of the Russian flag! Moreover, blue (as a variation of blue, i.e. whitened by pain) in conjunction with the gold, existential "I" is the flag of Ukraine, encoded in the line "Gold is paid for with blood of time" [3, p. 13]! In a poetic language, in close connection of thoughts and words, the deep meaning of unity and struggle of opposites, the "inner form" of thought, "sensual image" pulsates [5, p. 35], expressed using apperception [5, p. 37]. So, the purpose of identification and the meaning of life is to remain a Human until death ("honest and not mean is wanted" [3, p. 176]) and fulfill one's purpose by creating an honest portrait of the modern era with tears of blood.

Of course, the intonation of the motive of the path and the trace is different for each generation, but there are also common features. In particular, in the poem "Loneliness" by Joseph Brodsky (1959) this motive is implemented in the form of a "chipped ladder" [1], movement along which causes aesthetic disgust, and even physical tiredness from incredible efforts to keep the balance of "lame truths". The melting of chances to find understanding at home, multiplied by militant atheism in the USSR, could not help but reflect on the logos: the poet doubts even the conception of the Madonna Jesus. The state of loss 
of life balance, the reassessment of values in a boundary situation, the motive of a wanderer reluctantly aware of the narrowing of possibilities, became prophecy. In the "Pilgrims" by Brodsky, the feeling of being orphaned by the indifferent contemplation of travelers by the outside world is reinforced by the anaphora "by" and the "world will remain" refrain [1]. The wall of alienation between travelers and those who contemplate their movement grows psychologically as a self-suggestion: "And, therefore, believing in yourself and God / Will do no good. / ... And, therefore, only the illusion / and the road are left" [Same place. - A.TS.]. Recognizing his epoch as a "second-rate", and his thoughts "trophies of atruggle against suffocation" ("I said fate plays a game without a score"), Brodsky formulated two trajectories of a decent life - death from defending ("Fertilize its soldiers") and accept it for what it is ("Approve its poets"), thus echoing Aleksandr Blok: "I recognize you, life, I accept you / And I welcome you with the sound of a shield".

If Brodsky's language is fanciful, and the motive of climbing the stairs was inherent in the Irish Nobeliath Seamus Heaney, then Ihor Pavlyuk captivates with the simplicity of the vertical - from the mother's earthly soul to the cosmic fold of the soul. Moral and philosophical problems are complex, intonations are fanned by bright sadness, sometimes with irony and folk-poetical protracted legends.

In the absurdly unbalanced crisis and war world the poet's confession "between the cross and the chopping block" $[4$, p. 279] is metaphorically saturated with the verbalization of the internal states of the duality of body and soul, thirsting for the border meeting of God the poet with the "humanized" demon. The task of salvation involves the trinity: "Saving the body and the world from disintegration / And my hurting country" [4, p. 283].

The "earth-sky" vertical, the axis of spiritual connection with the dead serves as a pillar of the "Carrier of Dreams" artistic world. The cyclicality of the narrator's returns to the existential loss of the most dear people is transmitted as the twilight of the universe due to the destruction of harmony: "The sky has darkened, like the first bundle on the grave. / The string broke - the front mental line" [4, p. 3] and causes an allusion to the Twilight of the Gods. The horizontal in the coordinate system is delineated by linear movement along a specific route: "and the train shuffles". The earthiness of being causes bitterness not so much of the deliberate slowness of movement, which means that the passenger of the hostage is somehow doomed as by the way of a laughing cheap prostitute (possibly a crooked story?). And this laughter, obviously, forces the narrator to emerge from the memories, make out around, distract from the inner pain, in order to undergo the pain from the "market sadness of Ukraine" [Ibid. - A. Ts.]. The mood of the moth, the woman is in disagreement with the cordocentric sadness of the narrator, with popular moods in the era of squandering of the Motherland, the era of the leveling of values.

Geometry of connections is filled with blood and nerve, germinates with color and movement, where space hurts, and life is realized as the prelude of death. Maybe that's why an irreparable loss is accompanied by a state of weightlessness as independence and unbearable loneliness, as the loss of heart support ... Although the narrator seeks to hide pain behind a smile ("Weightlessness is ridiculous. / It's that easy that it's not interesting ...") [Same place. - A.Ts.], but a painful armor of laughter is punched by a desperately lonely tear. He will drink it with morning coffee - a symbol of the return from the night Universe of dreams and sufferings from the realization of their unsuitability to the everyday hustle and bustle...

Infinite thoughts about the essence of being are kind of set in motion by the image of the spindle of fate around the fast life of a man-candle: "And the night turns on the grave candle are melting" [Same place. - A. Ts.]. The image of the grave candle in its turn, becomes the impetus for a new round of confession, the essence of reality evaluation ("And the chocolate distance splashed with salty blood") and the rhetorical question: "Did really / All the colored dreams come true?.." [Same place. - A. Ts.]. A tragic vision of the irrationality of love in a sacrificial dimension unfolds between the two poles, materially physical and spiritually heavenly, divine and demonic in a human, on the border between life and death.

The external simplicity of the language of Ihor Pavlyuk's poetry is deceptive, because behind it lies a virtuoso mastery of poetic sociability thanks to a rare combination of children's openness to the world, youthful maximalist in interpreting popular aspirations and the energy of the word of a wise hermit who knows how to convey the finest mental states of a person. 
The author of almost fifty books of different genres, laureate of the People's Shevchenko Prize (Iron Mamai), the English PEN International Award, participant of international literary festivals and meetings in England, Germany, Georgia, Estonia, Russia, Belarus, Italy, Poland, Pakistan, Turkey, Ireland, The USA: Ihor Pavlyuk, is one of the most talented Ukrainian poets, whose work ability is amazing, whose works provoke a heated discussion on social networks every day, and every year pleases with new books.

In 2019, almost simultaneously with the "Carrier of Dreams", two more collections appeared "Salt" in English (New York) and "Crack", the translations of his poetry into Russian, so Ihor Pavlyuk can rightly say to himself: "I squeeze my life to a metaphor, / Like a certain World - in the uranium core, / Or millennia wine - amphoras...", "My words are taken to pieces, / Like temples to stones" [4, p. 124]. Contrary to the apocalyptic visions that resemble bleeding wounds, his poetic word as "the way to the Lord and himself" contains faith in the living grain of people, which will surely sprout along the heavenly vertical. Truths in their primeval simplicity are revealed to him: "Everyone is able to die abruptly, / But slowly... / This means living / On this planet" [4, p. 115]. The philosophical concept of turning the world when the masks are torn away, strives for the classification harmony represented by nominative rows between the poles: "Between the cross and the choker block / Sinners and saints" [4, p. 279]. The realities are inscribed in the crystal lattice of dominants, symbolizing material well-being, attitude to faith and native land, mankind is conventionally divided into categories: "warriors, actors, mongers" [4, p. 114], or a modified version: "politicians and media, / Rural uncles, poets, mongers" [4, p. 268]. As for the Ukrainian history, the writer without the extreme provocacy on the drama of intractable confrontations and the tragic consequences of three hundred years of assimilation: "Storks pass by the nest, / In the sky / Like crosses over the coffin" [4, p. 282].

Ingenious is always striking in its simplicity and extraordinary capacity: "Both cranes and butterflies ... / Horse bay. / Apocalypse in the "box". / Smoke. / Big Waters" [4, p. 122]. The chronicle of life with dreams, work, disappointments and global threats, the search for vital support and happy take-offs fit in the shortest possible lines, consciously almost devoid of trails. This is the simplicity of a poetically meaningful trajectory of human life, which borders, if you like, with the simplicity of the Dmitri Mendeleev periodic table of chemical elements.

The frequency of the comparisons usage by I. Pavlyuk cannot but draw attention. Alexander Potebnia argued the decisive role of comparisons in the cognition of the world by a child. Comparison is one of the ways to reveal the essence of things and phenomena [5, p. 255] in the process of concentrating thoughts and feelings. And, of course, one of the style signs: the freshness of the world perception with the help of a lens of comparisons. In the "Carrier of Dreams" compilation, they form clusters, acquire micro and telescopic properties, impart philosophical and now mundane mood, bring the seemingly incompatible together, blow consciousness with paradoxes, create an aura of mystery of knowledge and completely break the pathetic attitude to the object of the image expression: "I love to die as time dies. / But I don't like doing it as space does..." [4, p. 96], "the soul is faster than bullets" [4, p. 66], "The nests of souls are like saber glasses" [4, p. 112], "Life is like fishing / On a sunken boat" [4, p. 17], "So sad, like a funeral of God" [4, p. 120], "Death has big eyes, / Like a bee or a fly" [4, p. 285], "The Universe is silent, like a wine barrel. / Or like worms under the bark" [4, p. 249]. And this series can be continued.

Observing the state of mind of a contemporary, a person with a low pain threshold in an unbalanced world, I. Pavlyuk does not strive for one denominator. His answer is polyphonic, nuanced: "It became wild and shameless in the world... / where everything is corrupt, even the wind" [4, p. 114], where cranes fly like a graveyard [4, p. 205], "machine gun is shooting smoothly" [4, p. 206], "sleepy, dinosaurly" [4, p. 236], "labyrinthly" [4, p. 240], "laurelly-thornly", "cleansingly" [4, p. 273], "Judah" [4, p. 294] and "disgusting, hellishly and naked" [4, p. 247].

The poet operates with repetitions characteristic of the folk-song tradition, subtly confronts words that are close in sound. His poems sometimes remind of the process of the word discovery, its sound writing, subtle vibrations of semantics. He aspires to the simplicity of the people and the capacity of the utterance, so here comes the "circuit of tears", for the people will believe a mean tear over blood fates and a dear death. He is ready to catch the elusive - the shadow of a tear, a tear on the river water [4, p. 224], bestial love of life and plant love of death [4, p. 223], to feel "graves like deep native heavens" [4, p. 216]. 
In other words, the poet loves life incredibly in all its manifestations, loves it so much that he is ready to live forever and die, at any moment...

1. Бродский И. Стихи / Иосиф Бродский [Электронный ресурс]: https://rustih.ru/iosif-brodskij [Название с экрана.] Дата просмотра: 14.07.2019.

2. Врубель Л. Герменевтика / Лукаш Врубель // Література. Теорія. Методологія / пер. 3 польськ. С. Яковенка; Упор. і наук. ред. Д. Уліџької. 2-ге вид. К. : Вид. дім “Києво-Могилянська академія", 2008. С. 56-113.

3. Павлюк І. Паломник / Ігор Павлюк. К. : Вид-во “ФОП Ретівов Тетяна", 2018. 224 с. (Серія “Сучасна література. Поезія, проза, публічистика").

4. Павлюк I. Перевізник мрій: книга лірики / Ігор Павлюк. Харків : Майдан, 2019. 352 c.

5. Потебня О. Думка і мова / О. О. Потебня. Естетика і поетика слова : збірник; пер. з рос. упор., вступ. сл., прим. І. В. Іваньо, А. І. Колодної. К. : Мистецтво, 1985. 302 с. (Пам'ятка естет. думки).

6. Царук А. Струна над золотом снігів, або Межовий стан особистості в романі-медитаиії Ігоря Павлюка "Паломник" / Антоніна Царук // Слово і Час: науково-теоретичний журнал. 2017. C. 106-112.

7. Шевченко Т. І мертвим, і живим, і ненарожденним землякам моїм.../ Тарас Шевченко. Кобзар / вступ. ст. О. Гончара. К. : Дніпро, 1983. С. 288-294.

\section{References}

1. Brodsky J. Stihi / Josif Brodsky [Electronic resource]. Access mode: https://rustih.ru/iosifbrodskij [Josif Brodsky. Poems].

2. Vrubel L. Hermenevtyka / Lukash Vrubel // Literatura. Teorija. Metodologija / Per. z polsk. S. Jakovenka; Vpor. i nauk. red. D. Ulitskoji. 2-e vyd. K.: Vyd. Dim "Kyjevo-Mohylianska akademija", 2008. S. 56-113. [Vrubel L. Hermenevtyka / Lukash Vrubel // Literature. Theory. Methodology / Trans. from polish S. Jakovenko; Compiler and science. editor. D. Ulitskoji. 2 nd edition Kyiv: Publishing house “Kyivo-Mohylian Academy”, 2008. P. 56-113].

3. Pavliuk I. Piligrym / Ihor Pavliuk. K.: Vyd-vo "FOP Retivov Tetiana", 2018. 224 s. (Serija "Suchasna literature. Poezija, proza, publitsystyka") [Pavlyuk I. Pilgrim: the Poem / Ihor Pavlyuk. Kyiv: Publishing house "FOP Retivov Tetiana", 2018. 224 p. (Series "Contemporary Literature. Poetry, prose, journalism")].

4. Pavliuk I. Pereviznyk mrij : knyha liryky / Ihor Pavliuk. Harkiv : Maidan, 2019. 352 s. [Pavlyuk I. Carrier of Dreams : the lyric collection / Ihor Pavlyuk. Harkiv : Maidan, 2019. 352 p.]

5. Potebnia O. Dumka i mova / O. O. Potebnia. Estetuka i poetuka slova : Zbirnuk. Per. z ros., upor., vstup. sl., prym. I. V. Ivanio, A. I. Kolodnoji. K.: Mystetstvo, 1985. 302 s. [Potebnia O. Thought and language / O. O. Potebnia. Aesthetics and poetics of the word: collection / Trans. from rus. I. V. Ivanio, A. I. Kolodnoji. Kyiv :Art, 1985. 302 p.].

6. Tsaruk A. Struna nad zolotom snihiv, abo Mezhobyi stan osobystosti v romani-medytatsii Ihoria Pavliuka "Palomnyk" // Slovo I Chas: naukovo-teoretychnyi zhurnal. 2017. S. 106-112. [Tsaruk A. A String Over The Snow of Gold, or The Boundary State of Personality in Igor Pavliuk's Meditation Novel "Pilgrim" / Antonina Tsaruk // Word and Time. Scientific-theoretical journal. - 2017. P. 106-112].

7. Shevchenko T. I mertvym, i zhyvym, i nenarodzhenym.../Taras Shevchenko. Kobzar / Vstup. st. O. Honchara. K.: Dnipro, 1983. S. 288-294 [Shevchenko T. And both dead and alive and unborn... / Taras Shevchenko. Kobza. Kyiv : Dnipro, 1983. P. 288-294]. 